\title{
Taxonomy of the Psychosocial Consequences Caused by the Violence of Persecution of ETA's Network
}

\author{
Javier Martin-Peña ${ }^{1}$, Álvaro Rodríguez-Carballeira ${ }^{1}$, Jordi Escartín ${ }^{1}$, \\ Clara Porrúa ${ }^{1}$, and Miranda Olff ${ }^{2}$ \\ ${ }^{1}$ Universidad de Barcelona. (Spain) \\ ${ }^{2}$ University of Amsterdam. (The Netherlands)
}

\begin{abstract}
This paper delimits and analyzes the effects of the harassment perpetrated by ETA's terrorist network in the Basque Country. The aim was to provide a taxonomy of the consequences of psychological violence and to validate this taxonomy, by means of a content analysis of 37 testimonies of victims of terrorist violence. The taxonomy of consequences of psychological violence is made up by four components: 1 . the effects on the context of the persons affected, 2. on their emotional state, 3. on cognition and 4. on behavior. Results show a predominance of contextual consequences and negative cognitions. Intra-observer and inter-observer reliability analysis showed high stability and reproducibility coefficients. This study shows that harassment and psychological violence have major consequences not only for victims but also for family members, threatened collectives and even the society as a whole.
\end{abstract}

Keywords: psychological violence, harassment, terrorist violence, violence of persecution, content analysis.

\begin{abstract}
Este estudio delimita y analiza los efectos del acoso aplicado por el entramado terrorista de ETA en el País Vasco. El objetivo consiste en aportar una taxonomía de las consecuencias de la violencia psicológica y validar esta taxonomía, mediante un análisis de contenido de 37 testimonios de víctimas de la violencia terrorista. La taxonomía de consecuencias de la violencia psicológica se encuentra formada por cuatro componentes: 1. los efectos sobre el contexto de las personas afectadas, 2. sobre su estado emocional, 3. sobre la cognición y 4. sobre la conducta. Los resultados muestran una predominancia de las consecuencias contextuales y las cogniciones negativas. El análisis de la fiabilidad intraobservador e interobservador muestra unos adecuados coeficientes de estabilidad y reproducibilidad. Este estudio muestra que el acoso y la violencia psicológica tienen grandes consecuencias no solo para las víctimas sino para los familiares, los colectivos amenazados y para el conjunto de la sociedad.
\end{abstract}

Palabras clave: violencia psicológica, acoso, violencia terrorista, violencia de persecución, análisis de contenido.

The study was supported by the Spanish Ministerio de Ciencia e Innovación (PSI2010-16098) and the Fundación Víctimas del Terrorismo. We wish to thank, without implicating, anonymous referees and R. Gutiérrez, L. Cristóbal, N. Hurtado, L. Asúa, and P. Grados.

Correspondence concerning this article should be addressed to Javier Martin-Peña. Departamento de Psicología Social. Facultad de Psicología. Universidad de Barcelona. Mundet. Passeig de la Vall de Hebron, 171. 08035 Barcelona. (Spain). Fax: +34-934021366. E-mail: javier_martin@ub.edu 
ETA (Euskadi Ta Askatasuna - Basque Homeland and Freedom) terrorist attacks over the past decades have had a great influence on the life of victims and the society as a whole. Besides terrorist attacks (e.g. bombings), violence has usually been characterized by psychological violence, coercion and harassment (e.g. threats and intimidations) specifically in the Basque Country. According to the Basque Ombudsman Ararteko (2009a), ETA's terrorist violence in the Basque Country can be named violence of persecution (term named by Gesto por la Paz, 2000) because it implies coercions and death threats to some collectives, by their belonging to a certain political party or certain professional sectors.

However, this type of violence has been less studied than physical violence, and according to the World Health Organization (WHO, 2002), exists the need to include and research a form of violence that does not necessarily result in injury or death but which places a substantial burden on individuals, families, communities and health care systems worldwide (Krug, Dahlberg, Mercy, Zwi, \& Lozano, 2002). For instance, threats can be seen as a potential traumatic experience, which may be unpredictable, unpleasant, and cause feelings of intense helplessness (Nijdam, Olff, de Vries, Martens, \& Gersons, 2008).

In this line, this paper defines the psychosocial effects of harassment and psychological violence strategies perpetrated by ETA's terrorist network in the Basque Country, from the analysis of a number of testimonies of persons who have suffered what is so-called violence of persecution. The aim is not to make a clinical assessment of the psychological harm of people who suffer from this form of violence, but rather to propose a taxonomy of the psychosocial consequences that these people may endure in their daily lives. This violence and its effects have not been given much attention by researchers, existing very little publications about this phenomenon (Ararteko, 2009a). The definition of the consequences may be useful to increase the visibility of this violence, to recognise a new type of victims who have emerged from the terror engendered and according to Ararteko (2009a) for the social de-legitimizing of terrorist violence.

\section{Evolution of ETA's Terrorist Violence}

Since the 90's decade, ETA's violence evolved through different actors. The so-called ETA's network, which would be formed by collaborators and sympathizers, contributed to complement ETA's goals. For instance, the kale borroka (street fight) involved young people who often support the terrorist group, sometimes strategically organized, in the form of urban guerrilla tactics (Barros, Caporale, \& GilAlana, 2009).

Besides ETA's attacks (e.g. assassinations or kidnappings) these mentioned groups perpetrated some of the violence committed by the network, using both physical (e.g. bomb-making, aggressions or attacks on properties) and psychological violence (e.g. threats, insults or coercion) (Alonso \& Reinares, 2005; BartoloméGutierrez \& Rechea-Alberola, 2006; Llera \& Retortillo, 2005). Considering that people who have suffered physical violence often have previously endured psychological violence (Martin-Peña, Rodriguez-Carballeira, Escartín, Porrúa, \& Winkel, 2010), physical and psychological violence could be seen as a continuum.

According to Imbusch (2003), psychological violence is based on words, gestures, pictures or symbols, and is aimed at forcing others into subjugation through intimidation and fear (e.g. a picture with a death threat in a specific context). This violence, defined as systematic and continued perpetration of abusive behavior, achieves a wider degree of terror when interacting with physical violence or the risk of it being perpetrated, directed repeatedly and unpredictable against the target.

These new forms of violence fundamentally began from the strategy termed by ETA as socialization of suffering on 90's, signalling new and wider sectors of society as potential targets as they would have a greater impact on public opinion (De la Calle \& Sánchez-Cuenca, 2004 ; Sánchez-Cuenca, 2009). Thus, "people who have shown critics to the totalitarian ETA's project, such as democratic represents, judges, prosecutors, police, military, prison officers, journalists, university professors, and businessmen, among others, are under terrorist threat" (Ararteko, 2009b, p. 635). So, terrorism and its threat would achieve its aims not only using violent acts against targets but also using the resulting effects (Fromkin, 1975).

\section{Consequences of ETA's Network Violence}

The effects of terrorist violence may lead to significant psychiatric disorders such as acute stress disorder (ASD) and posttraumatic stress disorder (PTSD) (Danieli, Brom, $\&$ Sills, 2004). In addition to death and injures, terrorist violence often involve stress and anxiety responses, which include both psychological and physical expressions like concentration problems, sleep disorders, feelings of anxiety or a depressed mood, increased alertness, physical problems such as headache, stomach-ache, backache, fatigue, increased or diminished appetite, among others (Nijdam et al., 2008).

Attacks or physical violence often occur in as a single episode and may cause significant disruption to the victim, such as severe stress, and may manifest a pattern of dissociative anxiety symptoms (Echeburúa, 2004). Herman (1992) proposed the so-called Complex Post Traumatic Stress Disorder (CPTSD) which may occur in response to an event which happens repeatedly, in stead of a single isolated traumatic event. It has been identified in survivors of various forms of repetitive trauma, such as childhood physical abuse, or sexual abuse. According to De Jong, 
Komproe, Spinazzola, Van der Kolk and Ommeren (2005), it also occurs in situations where people are exposed to persecution, political repression, torture, or terrorism.

Some of these situations (e.g., persecution) have been perpetrated by the terrorist network in the Basque Country as forms of permanent and systematic harassment and continual threat, including murder. This violence of persecution involves a series of consequences such as feelings of persecution, isolation and vulnerability (Gesto por la Paz, 2000).

This situation of violence involves threats and close protection, which often results from such threats. The model threat, close protection, and consequences for professional practice and private life, proposed by Nijdam et al., (2008) shows the connections between stressors, personal reactions and consequences. Different threats and the resulting protection have an impact on the life of the threatened person and his/her environment.

The consequences vary in function of the type of violence perpetrated, that is, whether it is physical or psychological. Studies on the effects among victims of terrorist violence in Spain showed that people who survived a terrorist attack had a high risk of depressive and anxiety disorders, as well as worse levels of mental health than the general population in both the short and long term (Baca, Cabanas, \& BacaGarcía, 2002; Baca, Cabanas, Pérez-Rodríguez, \& BacaGarcía 2004). Recent studies in the Basque Country have shown that victims of terrorist violence have between 4 and 7 times more risk to suffer physical, emotional and psychiatric pain (Larizgoitia, Izarzugaza, \& Markez, 2009). In the case of indirect victims, the psychopathological effects may be greater when the direct victim survives the attack, but is severely disabled and in need of constant care, than when he or she is killed (Echeburúa, de Corral, \& Amor, 2002).

Contrary to the cases of physical violence, threatened persons in the Basque Country, who might suffer harassment and psychological violence, may suffer from effects such as anxiety, symptoms of depression, drugs abuse and couple problems, as an expression of intimate suffering (Echeburúa, 2004). There is little research on the effects of the abovementioned violence of persecution in the Basque Country, which not only affects direct victims but also their relatives, friends and neighbours by means of a continual environment stress factor (Gesto por la Paz, 2000). According to Pereira (2004), some of the consequences of this violence may include social stigmatization, which can affect the social-environment of the victim, and also a decreasing of social support. According to Baca, Echeburúa, and Tamarit (2006), the studies about terrorism pointed out the relevance of social support as a protection factor against psychopathological consequences. Changes in routines due to security reasons, use of close protection, anxiety symptoms, increase in substance abuse or sedative medication, continued fear, uncertainty and stress, may be other effects in victims of that violence.
Therefore, the effects of violence of persecution and the strategies of psychological violence perpetrated by ETA's network should be studied accurately from a social and scientific approach. It seriously disturbs the daily life of a large number of people, and there is little analytical and normative research (Ararteko, 2009a).

\section{Aims}

According to the above-mentioned, the general aim of this study consists of defining and classifying the negative consequences of the harassment and psychological violence strategies perpetrated by the terrorist network in the Basque Country, which may be suffered fundamentally by a sector of the population who have endured different levels of intensity of threats and violence. This approach is similar to other studies on situations of psychological violence and harassment, such as for instance, stalking or bullying in the workplace for which have been proposed typologies of abusive strategies and violence effects (Escartín, Rodríguez-Carballeira, Zapf, Porrúa, \& MartinPeña, 2009; Martin-Peña, Rodriguez-Carballeira, Escartín, Porrúa, \& Winkel, 2010; Nijdam et al., 2008; RodríguezCarballeira, Escartín, Visauta, Porrúa, \& Martín-Peña, 2010; Spitzberg, 2002).

From these precedents, two specific aims have been proposed:

1) To propose a taxonomy of psychosocial consequences of harassment methods or strategies perpetrated by ETA's terrorist network.

2) To contrast and validate the taxonomy constructed by means of a content analysis of the testimonies of victims who have suffered the consequences of harassment perpetrated by the terrorist network.

\section{Method}

\section{Participants}

The participants were 37 testimonies that have been targeted by ETA or affected by the harassment perpetrated by the network in the Basque Country. Characteristics of the sample are shown in Table 1 . The first 18 testimonies were collected from several types of public documents (e.g. documentaries and interviews in magazines, newspapers, audiovisual material produced by associations of terrorism victims).The other 19 were collected from written extracts using snowball sampling, because of the sensitive nature of the topic as well as the increase in attitudes of distrust by such people (Pereira, 2004). Penrod, Preston, Cain, and Starks (2003) pointed out that conceptual underpinning of snowball sampling is that members of a special population are familiar with others in that population. These authors consider snowball sampling may be useful for accessing 
Table 1

Characteristics of the sample

Main characteristics of the sample

\begin{tabular}{llcc} 
Variables & & $\begin{array}{c}\text { Testimonies } \\
(n=37)\end{array}$ & Percentage (\%) \\
\hline Gender & Male & 24 & 64,86 \\
& Female & 13 & 35,14 \\
Age range & Less than 40 years & 10 & 27,02 \\
& From 40 to 49 years & 16 & 43,24 \\
& 50 or more years & 11 & 29,73 \\
\multirow{2}{*}{ Professional sector } & Private & 11 & 29,73 \\
& Public & 26 & 70,27 \\
Motive of persecution & Political activity & 25 & 67,57 \\
& Public critics to ETA network & 7 & 18,92 \\
& Relative of target & 2 & 5,41 \\
& Professional activity & 3 & 8,11 \\
\hline
\end{tabular}

hidden populations, hard to reach populations or sensitive topics, such as people threatened by ETA.

\section{Procedure}

The study has been fulfilled between September 2008 and February 2009. A wide review of the studies on this topic and face-to-face interviews with targets of the abovementioned violence of persecution was carried out in order to develop a taxonomy of psychosocial consequences. The public testimonies dated from 2004 to 2009, and the written testimonies dated from 2009.

A request for collaboration was specifically e-mailed to "threatened" people by ETA and to people with relation with them, for motivating and getting their experience and effects about suffered violence. The document presented the aim's research, emphasizing the usefulness of their collaboration and the use of the data without compromising safety. A website address was included in the document for contributing the experience anonymously. So, sociodemographic data and written testimonies of violence were received electronically, by means of QuestionPro software. Considering the sampling used, there was not a standard informed consent because the sample was indirectly contacted. Content analysis of publicly available data and written testimonies using snowball sampling enables an initial approach to a topic where samples represent a hidden population who are frightened about talking about this situation. Considering the very sensitive nature of the issue the sampling here was done using the non-probability method. Furthermore, probability method sampling would require a very wide sample of persons in order to ascertain a percentage of victims in society.

\section{Development of the Taxonomy}

In order to achieve the first aim of the present study, a revision of the literature and the interviews were done for developing the taxonomy of psychosocial consequences of harassment methods or strategies perpetrated by ETA's terrorist network. Hence, the psychological violence consequences were identified, grouping them by means of a psychosocial approach. In order to achieve the second aim, testimonies were coded in the categorization or taxonomy, using a deductive content analysis (Mayring, 2000).

\section{Unit of analysis}

According to Holsti (1969) the units of analysis are defined as a specific segment of content that is characterized to ascribe it to a specific category. The effects or consequences of psychological violence in their different forms, resulting from the violence perpetrated by the terrorist network, were defined as units of analysis.

\section{Codification}

Audiovisual testimonies were transcribed, attaching them to an ASCII file for the content analysis. Codification and grouping of the units was carried out using Hyperresearch 
2.8 software. Rules of presence and absence were employed. The frequency (f) of categories in each unit of analysis was quantified. Units of analysis were coded by two external coders in order to verify concordance or reliability. Coders received coding agenda or instructions, which comprised the code name, text examples, and coding rules.

\section{Coder Reliability}

Intra-coder and inter-coder reliability was carried out in order to verify the concordance in the codification process of the testimonies of the violent acts into the categories. Inter-coder reliability was made to ensure that different coders agree on the coding of the same text. Intra-coder reliability was also carried out to ascertain the stability of the coding of each coder. Kappa Cohen's was used as the reliability coefficient, using SPSS-15 software.

\section{Results}

According to the first aim, results obtained consist of a taxonomy of the consequences or effects possibly suffered by harassed people or groups at risk who have been signalled by the terrorist network in the Basque Country (See Table 2). These consequences result principally from psychological violence, which might be direct, (i.e. people suffering from insults, threats or others) or diffuse (i.e. belonging to a group at risk). The taxonomy of psychological violence effects is divided into four groups of effects that emphasise psychosocial components: (1) contextual, (2) cognitive (3) emotional and (4) behavioral aspects. Each one of these groups is divided into subcategories of specific effects. Each subcategory is labelled as a function of the consequences which predominate in each of them.

According to the second aim, content analysis is shown, with the testimonies coded into the categories and sorted in descending order by frequency $(f)$ (See Table 2). Coder reliability using Kappa Cohen's index (к) is shown. The intraand inter-coder agreement in the codification have shown a good level of reliability, with a stability and reproducibility index of $\kappa=.95$ and $\mathrm{\kappa}=.89$, respectively. In addition, some literal examples extracted from the testimonies analyzed are shown in each category.

Consequences included in the category Context (see Table 2) were the most highly scored among the testimonies $(f=88)$. This refers essentially to effects that influence the person's surrounding context. Specifically, the sub-category with the highest frequency was The need for protection measures. The use of escorts or bodyguards is common when the person has suffered some kind of harassment or belongs to a group at risk, with this close protection being useful in reducing the risk of aggression and murder. For instance: I am a councillor in a village with 5000 inhabitants. I don't make a living from politics. I've had a bodyguard since 2000. I remember that I was pregnant at the time with my second daughter. I was protected in the maternity hospital where I gave birth.

And: You have to live with a fire extinguisher... you have to live with protected glass windows... with a reinforced door.

The second sub-category in frequency was Disorder in social activities, which affects daily routines, with continual changes in schedules and itineraries as well as the need to avoid certain activities that might be a risk for the person. These risk activities are often daily tasks: I usually don't take or pick up my daughters from school although my working hours would allow me to do so. I don't take them to the park because the world of children is full of routines and it is precisely routines which could spell our death sentence. I try not to go into the street at the same time as they do because the moment when you are most vulnerable to suffering an attack is when you are leaving your home. In part, Disorder of social activities is related to the use of bodyguards, but the main consequence of this lies in the direct or diffuse strategies of harassment which some people suffer. People who reject the use of bodyguards must also change their social activity routines, using selfprotection measures. Hence, irrespective as to whether people use security measures or not, their social activities will be negatively affected.

Thirdly, the atmosphere created by the harassment might facilitate the Disorder in family relations in different ways. The worry that harm may come to a member of the family may affect negatively that relationship: You reach the moment when you are so overwhelmed (by the harassment situation) that it can even affect your relationship with your partner.

Also: The kids are growing up and they are growing up in a strange environment ... and you don't know how this can affect things in the future.

Or: My parents see that you aren't free to do what you want and that you are threatened, they don't understand the situation and they don't understand why you get involved in politics* when you have a job. (*He is a councillor).

Fourthly, Distancing significant social relations is shown. This may occur both in professional or friendship contexts. People may not want to have a relationship with the harassed or stigmatized person: I have also felt other people distancing themselves from me in several places which I'm not going to mention. This is particularly painful because you realise that you are in the way and that people don't want to be with you very much.

Also: Since I became a councillor my "friends" have turned their backs on me. People may prefer not to visit the threatened or targeted person because they are afraid of being in danger or becoming the target of a threat. This can be intensified when it affects spouses, partners, children, friends or neighbours.

Finally, because situations of harassment may become continual, some people find it necessary to move: We have had to move house several times. 
Table 2

Taxonomy and resultant frequency (f) of psychosocial consequences of harassment and psychological violence perpetrated by terrorist network in the Basque Country

Taxonomy of psychosocial consequences

1. Person's Context

1.1. Necessity of protection and security measures

1.2. Disorder in social activities, in the routine and daily plan

1.3. Disorder in family relations

1.4. Distancing significant social relations

1.5. Necessity move address

2. Cognition

2.1. High perception social vulnerability and freedoms restriction

2.2. Death thoughts or thought about the risk for the life

2.3. Exhaustion and thoughts of abandoning the situation

2.4. Distrust and concealing the situation experienced

2.5. High perception of social stigma

3. Emotion

3.1. Fear

3.2. Stress, anxiety

3.4. Indignation, anger

3.3. Sadness, depression, self-isolation

3.5. Aversion strong and a continued lost of interest social daily situations

4. Behavior ${ }^{2}$

4.1. Taking of medication

4.2. High consumption of alcohol or other illegal drugs

Units of analysis coded

Inter-coder reliability for all codes

Intra-coder reliability for all codes ${ }^{3}$

Note. ${ }^{1}$ Codes are in descending order of frequency. ${ }^{2}$ It was not find any behavioral category in analyzed testimonies. ${ }^{3}$ Test-retest with an interval of a month

The category of Cognition $(f=50)$ (see Table 2) was the consequence with the second highest score and refers to perceptions or thoughts as an effect of the situation of harassment. Specifically, the point with the highest frequency is High perception of social vulnerability and freedoms restriction, emphasizing the uncontrollability of the situation and lack of freedom in different ways: In the end, you feel there is no freedom to be yourself, and your ideology is your death. You are better sitting at home.

Secondly, the effect Death thoughts or thoughts about the risk for the life may be quite usual when faced with harassment strategies, and is especially intense when there is some act of physical violence. It can be directed towards another person but does however increase the cognition perception of death thoughts: When you leave home, you aren't sure if the enemy is preparing a 'surprise'* or if you will be hunted on that day. (*meaning an attack).

Also: The saddest thing about this situation is that a lot of us have thought on so many occasions that we can be murdered every day. Or: If they murder a newspaper accountant, why won't they kill me?

The third most frequent subcategory was Exhaustion and thoughts of abandoning the situation: You do don't want to continue, though you know that if you do leave, you will also be at risk. It is not worth it. Somebody must stand up for the country, but it'd be better if other people did it. Because of the different kind of pressure suffered, some people may decide to abandon the situation they are in. Also: You think about going away from here. 
The fourth most frequent subcategory was Distrust and concealing the situation experienced. When situations of harassment begins, the need to hide it and attitudes of distrust can become extreme, with people thinking continuously about who is suspect of being a collaborator of the terrorist network: When two keys to my house appeared wrapped in two death threats, I logically thought bad of some of my neighbours. Also: You go out with people who don't know the situation, and you don't tell them about it... You are living with lies, living a second life. The situation of harassment might engender a High perception of social stigma, for instance, especially people using a bodyguard or living in a small village. For instance: You are labelled as somebody who is excluded from society.

The category of Emotion $(f=17)$ (see Table 2$)$ refers to how personal, emotional reactions are affected, essentially encompassing fear, stressful situations, sadness or aversions. The first subcategory is fear: I have to stay at home... because I'm frightened of going out at some times. This fear may also refer to fear of suffering an attack but also of being stigmatized, being in certain places, being isolated or excluded, amongst other. Secondly, there are situations of anxiety and stress, which are quite common: Sometimes I'd see couple of guys I didn't know. They'd approach me and I said to myself, 'These are the ones who are going to kill me'. They went by, I sighed and said to myself 'You are going mad'. Thirdly, is the Indignation, anger that can be considered as an emotional reaction, which might be directed at the person's socialenvironment, or towards people perceived by victims as directly or indirectly responsible for the situation of harassment: (Sympathizers of ETA's network) put up a big banner insulting me in front of my home. When I saw it, there was a Basque autonomous police van that seemed to be guarding it, and I couldn't understand why they wouldn't pull it down. I got angry and they pulled it down. According to Nijdam et al. (2008), people may respond to this situation with increasing irritability expressed by feelings of irritation, anger or outbursts of rage.

Sadness, depression and self-isolation was the fourth category which may appear as an effect of continued stress situation: As a consequence of the situation we are slowly shutting ourselves off in our work and our home. The subcategory of Strong aversion and a continual lost of interest in social daily situations wasn't reflected in testimonies. However, avoiding and diminished interest in activities or places may be reactions to a traumatic event.

The Behavior category (see Table 2), comprises the subcategories Taking medication and High consumption of alcohol or other illegal drugs. It refers to certain risk behaviors that might be done by the person suffering the harassment, as compulsive behaviors. This effect has not been scored in the sample, after the testimonies analysis.

\section{Discussion}

This paper focuses on the psychosocial effects of psychological violence strategies perpetrated by ETA's terrorist network in the Basque Country. Considering that these effects may impose a chronic stress on the people that suffer this terrorist violence, a taxonomy that aims to contribute towards improving the knowledge of this topic and defining consequences of the above-mentioned violence of persecution is proposed.

The evolution of ETA's terrorist violence, in terms of its organisational structure, strategies of violence, and selection of targets has caused harm or negative consequences by both direct and indirect victims in the Basque Country This evolution has involved effects of political persecution such as the ones analysed here, which principally began with ETA's aim for the socialization of suffering. It has been chiefly directed at people who have criticized ETA's totalitarian project (Ararteko, 2009b).

From a Bio-Psycho-Social approach of health, chronic stress may lead to frequent or prolonged activation of the neuroendocrine stress systems, in turn causing enduring mal-adaptations in biological regulatory mechanisms (Olff, Langeland, \& Gersons, 2005). PTSD as a deregulation of the fear system according to Gersons and Olff (2005), may cause persistent symptoms and co-morbidities. Anger and hostility also appear to be central attributes of traumatized individuals suffering from PTSD (Winkel, 2007). However, in addition to biological and psychopathological effects, psychosocial consequences play a significant role in the health of victims of a continued violence, including factors such as the quality and density of social networks support (Pedersen, 2002). The taxonomy proposed indicates the potential depth and breadth of strategies of psychological violence and its effects, which can dominate the person's life.

Results obtained highlight the power of abusive psychological violence behaviors, such as threats or other acts of intimidation, which lead to a wide range of consequences. By using testimonies of victims, the usefulness of the proposed taxonomy permits to establish an initial hierarchization of the relevance of the different effects of terrorist psychological violence. The frequency obtained emphasises, firstly, the context, and to a lesser degree, cognition and emotional aspects. Thus, some studies have shown areas which may be affected by similar kinds of violence strategies. For instance, Spitzberg (2002) in romantic relationships, emphasized the effects of stalking, including some similar categories to the taxonomy proposed in this paper, covering wider aspects that include effects such as general disturbance, affective health, cognitive health, physical health, social health, resource health, and health resilience. As well, Escartín, Zapf, Arrieta, and RodríguezCarballeira (2011) in a cross-cultural study between Southern European and Central American employees, found a similar pattern of categories when analysing self-reported definitions of workplace bullying. 
Disruption in the contextual aspects is an important source of chronic stress, which may facilitate a loss of social support. This support is a relevant protection factor for victims, covering the social environment of the person and institutional social support (Echeburúa, de Corral, \& Amor, 2002). The research by Baca and Cabanas (2003) on victims of terrorism in Spain, showed that more than half of the sample felt that they had been abandoned by society. The change of routines because of the situation of harassment or also when faced with a situation of risk, may cause intense unease and professional practice may be affected. It is difficult to give up routine behaviors, which helps form the identity of the person, but the non-fulfilment of these routines has sometimes led to killings in the Basque Country (Pereira, 2004). These murders increase and reinforce the strategy of persecution. In addition, the use of close protection, (i.e. bodyguard) and the constant involvement with protection officers may reinforce the sense of a threat (Nijdam et al., 2008). A significant number of people threatened in the Basque Country, (e.g. councillors of non-nationalist political parties, among others), who are often not professional politicians, must combine this activity and stressful situation with their work, study or other daily activities. If these stressful situations continue, and the person has no option to move to another geographical area, it may increase both stress symptoms and a strong perception of rejection (Echeburúa, 2004). From this situation of threat and close protection, where politicians are a high-risk population, some people may be indirectly coerced, and some may not wish to be involved in politics.

Perception and thought processes may be influenced by harassment and psychological violence strategies, changing assumptions of life into a sense of extreme vulnerability. Olff, Langeland \& Gersons (2004) pointed out that cognitive appraisal and coping processes may be relevant (co)determinants of the psychological and physiological stress response. Death thoughts arise because the threatened person does not know the risk or possibility of suffering an attack, and the threat may become a continual factor of uncertainly (Echeburúa, 2004). This situation often creates a sense of exhaustion, and when it is continual, some people may decide to leave the Basque Country (Pereira, 2004). According to this author, persecution symptoms frequently appear together with attitudes of distrust. People threatened may suddenly start suspecting other people who look at them in a certain way, thinking that they are planning an attack, without having any real evidence for such a suspicion, it being a dysfunctional cognitive interpretation (Nijdam et al., 2008). Concealing the situation may occur because a person who is a target or a potential target of ETA may be stigmatized in his/her social context, which might result in a loss of social support and even in the subsequent perpetration of violence.
All of this affects the emotions of persons, creating a range of fears in the target person, who may be afraid of suffering an attack, being stigmatized by society, or afraid of something happening to relatives. According to Tucker (2003), terrorists seek to invoke a pervasive fear in the civilian population by personalizing the threat so that everyone feels vulnerable, regardless of the statistical probability that a given individual will be affected. So, a continual state of alert may lead to anxiety symptoms and finally depression (Echeburúa, 2004). The appearance of avoidance reactions is possible, along with depressive moods, hyperarousal, difficulties in sleeping and concentrating, and increased irritability or anger.

Risk behaviors, such as excessive alcohol consumption or other substances, do not appear in the testimonies we looked at, probably because of the sensitivity of such an intimate issue. The limitations of the sample of testimonies and the sensitivity of the issue, on medication, alcohol or drugs, could explain these results. Sensitive questions or topics, "is a broad category that encompasses not only questions that trigger social desirability concerns but also those that are seen as intrusive by the respondents or that raise concerns about the possible repercussions of disclosing the information" (Tourangeau \& Yan, 2007, p. 1).

However, these aspects are often common among people threatened in this kind of situations (Ararteko, 2009a; Nijdam et al., 2008; Pereira, 2004). For instance, certain toxic products or medicine is frequently self-administered, given the fear of the threatened person without visiting or consulting the health professional (Pereira, 2004). Some of these behaviors would be an indirect effect of the continual pressure and harassment situation, which may be used by the person as a palliative coping strategy in order to reduce symptoms of hyperarousal (Nijdam et al., 2008). Though these aspects may be seen as coping strategies, diffuse threats perpetrated by the terrorist network should be considered as the essential origin of the resulting psychosocial effects on the person and his/her environment, which can be modulated by help such as social support.

According to Nijdam et al. (2008), the above-mentioned situations where there are threats and often protection can be divided into two stages. In the early stage, the person is confronted for the first time with threat and protective measures and it can be seen as an acute stressor. Late on, in a second stage, where a certain degree of acclimation is common, both threat and protection can constitute a source of chronic stress.

Nature, severity, and temporal characteristics of traumatic events may vary, as do individual responses, and according to Herman (1992), it is more accurate to conceptualize the human trauma response as a spectrum. A continual perpetration of a diffused threat from different intensity has been perpetrated in the Basque Country in order to pressure on targets. It permits a permanent state of threat to exist among those signalled as targets of ETA. 
Interaction between physical and psychological violence achieves a significant level of threat, in the face of the situation of uncertainty which has consequences for the health of those directly involved. Thus, the suffering experienced by people who do not suffer direct attacks, often appears to be directly related to their proximity to the direct victims (Rodriguez-Carballeira \& Javaloy, 2005).

The degree of psychological harm is mediated by a number of factors (Echeburúa, Corral, \& Amor, 2002). These include, for instance, the intensity and perception of the event, the unexpectedness of the crime and the real level of risk suffered, the vulnerability of the victim, the possible concurrence of other problems, the social support received, and the psychological resources for coping available. Active coping may help individuals to deal with the traumatic stressor, preventing long term physiological dysregulation and post trauma symptoms (Olff, Langeland, \& Gersons, 2005). Hence, it will be necessary to assess accurately the intensity and type of aggression, psychological violence strategies and physical violence, the consequent effects, and the social context where the violence occurs.

In the last years, this context in the Basque Country has been formed by continual harassment, reinforced by selective attacks. As Van den Broek (2004) pointed out, there was an inverse relationship between ETA attacks and the intensity of kale borroka, playing it an alternative role to the terrorist murders (De la Calle, 2007). For instance, the murder by ETA of an ex-councillor on 2008, could reinforce the feeling of threat and fear, and even increase the range of potential targets. It has been used to signal wider sectors of society as potential targets and to put pressure on Basque society. This makes terrorism a social communication mechanism, which is based on violence and threats, and is aimed at modifying behavior by combining coercion and persuasion (Schmid, 2004).

The use of terrorist violence in the Basque Country has effects on Basque society by creating insecurity and fear. According to Martin-Peña, et al. (2010), ETA relies, firstly, on the support of a very considerable social network structure in the Basque community and secondly, on a "social silence" of a significant part of that society. The "social silence" in the Basque Country may accomplish a wider level of isolation for victims, which is a relevant risk factor for health. Hence, the unidirectional exclusion of the targets considered as enemies by ETA is sought, by means of an insidious and instrumental violence and the psychosocial consequences resulting from them.

\section{Limitations and future research}

Limitations of the research include the number and type of testimonies which cannot be representative. Some of them are public testimonies. The categories proposed may have some overlap. However, this enables an initial study of the reality of psychological violence that is very difficult to gain access to, and in which exists a relevant hidden victimization (Ararteko, 2009a). However, the resulting practical implications may be directed in order to carry out future research and awareness-raising plans with the aim of de-legitimizing the terrorist violence in the Basque Country.

This paper is focused on and contributes specifically to the consequences of ETA's violence from a psychosocial approach and without making a personal assessment of the psychological situation of each person. A broader role for preventive mental health strategies targeting all potential victims of terrorist attacks should be developed, seeking promote resilience in people exposed to traumatic events (Matt \& Vázquez, 2008). Future studies focusing on the impact of these terrorist acts on victims may contribute towards the decision to develop standards in the field of continuing assistance, access and administration of justice and compensation for victims of terrorism (Letschert, Staiger, \& Pemberton, 2009). In addition, health and treatment interventions, and legal and institutional responses should be developed in order to prevent and to minimize the negative consequences for society and more specifically, for direct and indirect victims.

\section{References}

Alonso, R., \& Reinares, F. (2005). Terrorism, human rights and law enforcement in Spain. Terrorism and Political Violence, 17, 265-278. doi:10.1080/09546550490520727

Ararteko (2009a). Atención institucional a las víctimas del terrorismo en Euskadi [Institutional attention to victims of terrorism in the Basque Country]. Retrieved from http://www. ararteko.net.

Ararteko (2009b). Informe al Parlamento Vasco 2008 [2008 Report to the Basque Parliament]. Retrieved from http://www. ararteko.net.

Baca, E., Echeburúa, E., \& Tamarit, J. M. (2006). Manual de victimología [Handbook of victimology]. Valencia: Tirant Lo Blanc.

Baca, E., \& Cabanas, M. L. (2003). Las víctimas de la violencia. Estudios psicopatológicos [The victims of violence. Psychopathological studies]. Madrid: Triacastela

Baca, E., Cabanas, M. L., \& Baca-García, E. (2002). Impacto de los atentados terroristas en la morbilidad psiquiátrica a corto y largo plazo [Terrorist attacks and short-long time psychiatric morbidity]. Actas Españolas de Psiquiatría, 30(2), 85-90.

Baca, E., Cabanas, M. L., Pérez-Rodríguez, M. M., \& BacaGarcía, E. (2004). Trastornos mentales en las víctimas de atentados terroristas y sus familiares [Mental disorders in victims of terrorism and their families]. Medicina Clínica, 122, 18, 681-685.

Barros, C. P., Caporale, C. M., \& Gil-Arana, L. A. (2009). Basque Terrorism: Police Action, Political Measures and the Influence of Violence on the Stock Market in the Basque Country. Defence \& Peace Economics, 20(4), 287-301. doi:10.1080/10242690701750676 
Bartolomé-Gutierrez, R., \& Rechea-Alberola, R. (2006). Violent youth groups in Spain. Young, 14(4), 323-342. doi: $10.1177 / 1103308806068547$

Danieli, Y., Brom, D., \& Sills, J. (2004). The trauma of terrorism. Journal of Aggression, Maltreatment and Trauma, 9(1), 1-17. doi:10.1300/J146v09n01_01

De la Calle, L. (2007). Fighting for local control: Street violence in the Basque Country. International Studies Quarterly, 51(2), 431-455. doi:10.1111/j.1468-2478.2007.00458.x

De la Calle, L., \& Sánchez-Cuenca, I. (2004). La selección de víctimas en ETA [Target selection of ETA's victims]. Revista Española de Ciencia Política, 10, 53-79.

De Jong, J. T. P., Komproe, I. H., Spinazzola, J., Van der Kolk, B. A., \& Ommeren, M. (2005). DESNOS in three postconflict settings: Assessing cross-cultural construct equivalence. Journal of Traumatic Stress, 18(1), 13-21.

Echeburúa, E., de Corral, P., \& Amor, P. J. (2002). Evaluación del daño psicológico en víctimas de delitos violentos [Evaluation of psychological harm in the victims of violent crime]. Psicothema, 14, 139-146.

Echeburúa, E. (2004). Superar un trauma. Tratamiento de las víctimas de sucesos violentos [Overcome a trauma. Treatment of violence victims]. Madrid: Pirámide.

Escartín, J., Rodríguez-Carballeira, A., Zapf, D., Porrúa, C., \& Martín-Peña, J. (2009). Perceived severity of various bullying behaviors at work and the relevance of exposure to bullying. Work and Stress, 23(3), 191-205. doi:10.1080/02678370903289639

Escartín, J., Zapf, D., Arrieta, C., \& Rodríguez-Carballeira, A. (2011). Workers' perception of workplace bullying: A crosscultural study. European Journal of Work and Organizational Psychology. First published on: 07 July 2010 (iFirst). doi:10.1080/13594320903395652

Fromkin, D. (1975). The Strategy of Terrorism. Foreign Affairs, 53(4), 683-698. doi:10.2307/20039540

Funes, M. (1998). Social responses to political violence in the Basque Country. Peace movements and their audience. Journal of Conflict Resolution, 42(4), 493-510. doi:10.1177/0022002798042004005

Gersons, B. P. R., \& Olff, M. (2005). Coping with the aftermath of trauma. British Medical Journal, 330, 1038-1039. doi:10.1136/ bmj.330.7499.1038

Gesto por la Paz (2000). Ante la violencia de persecución [Faced with violence of persecution]. Retrieved from http://www. gesto.org/violenciapersecucion.htm.

Herman, J. L. (1992). Complex PTSD: A syndrome of survivors of prolonged and repeated trauma. Journal of Traumatic Stress, 5, 377-391. doi:10.1002/jts.2490050305

Holsti, O. (1969). Content analysis for the social sciences and humanities. Reading, MA: Addison-Wesley.

Imbusch, P. (2003). The concept of violence. In W. Heitmeyer, \& J. Hagan (Eds.), International handbook of violence research (pp. 13-39). Dordrecht/Boston/Londres: Kluwer Academic Publishers
Krug, E. G., Dahlberg, L. L., Mercy, J. A., Zwi, A. B., \& Lozano, R. (2002). World report on violence and health. Geneva: World Health Organization.

Larizgoitia, I., Izarzugaza, I., \& Markez, I. (2009). La noche de las víctimas [The night of the victims]. Vitoria: Fundación Fernando Buesa Blanco.

Letschert, R., Staiger, I., \& Pemberton, A. (2009). Assisting victims of terrorism: Towards a European standard for justice. Dordrecht: Springer. doi:10.1007/978-90-481-3025-2_6

Llera, F. J., \& Retortillo, A. (2005). Los Españoles y las víctimas del terrorismo [The Spaniards and victims of terrorism]. Madrid: Centro de Investigaciones Sociológicas.

Martin-Peña, J, Rodríguez-Carballeira, A., Escartín, J., Porrúa, C., \& Winkel, F. W. (2010). Strategies of psychological terrorism perpetrated by ETA's network: delimitation and classification. Psicothema, 22(1), 112-117.

Matt, G. E., \& Vázquez, C. (2008). Anxiety, depressed mood, self-esteem, and traumatic stress symptoms among distant witnesses of the 9/11 terrorist attacks: Transitory responses and psychological resilience. The Spanish Journal of Psychology, 11(2), 503-515.

Mayring, P. (2000). Qualitative content analysis. Qualitative Social Research, 1(2), Retrieved from http://www.qualitativeresearch.net/index.php/fqs/article/view/1089/2386.

Nijdam, M. J., Olff, M., de Vries, M., Martens, W. J., \& Gersons, B. P. R. (2008). Psychosocial effects of threat and protection. Amsterdam: National Coordinator for Counterterrorism. Retrieved from http://english.nctb.nl/

Olff, M., Langeland, W., \& Gersons, B. P. R. (2005). The psychobiology of PTSD: coping with trauma. Neuroscience \& Biobehavioral Reviews, 29, 457-467. doi:10.1016/j. psyneuen.2005.04.009

Pedersen, D. (2002). Political violence, ethnic conflict, and contemporary wars: broad implications for health and social well-being. Social Science \& Medicine, 55, 175-190. doi:10.1016/S0277-9536(01)00261-1

Penrod, J., Preston, D. B., Cain, R. E., \& Starks, M. T. (2003). A discussion of chain referral as a method of sampling hard-toreach populations. Journal of Transcultural Nursing, 14, 100107. doi:10.1177/1043659602250614

Pereira, R. (2004). Violencia de persecución en el País Vasco [Violence of persecution in the Basque Country]. Perspectivas Sistémicas, 81. Retrieved from http://www.redsistemica.com. ar/pereira.htm.

Rodríguez-Carballeira, A., Escartín, J., Visauta, B., Porrúa, C., \& Martín-Peña, J. (2010). Categorization and hierarchy of workplace bullying strategies: A Delphi survey. The Spanish Journal of Psychology, 13(1), 297-308.

Rodríguez-Carballeira, A., \& Javaloy, F. (2005). Psychosocial Analysis of the collective processes in the United States after September 11. Conflict Management and Peace Science, 22, 201-216. doi:10.1080/07388940500200716

Sánchez-Cuenca, I. (2009). Analyzing temporal variation in the lethality of ETA. Revista Internacional de Sociología, 67(3), 609-629. doi:10.3989/ris.2008.03.24 
Schmid, A. (2004). Frameworks for conceptualising terrorism. Terrorism and Political Violence, 16(3), 197-221. doi:10.1080/09546550490483134

Spitzberg, B. H. (2002). The Tactical Topography of Stalking Victimization and Management. Trauma, Violence, \& Abuse, 3(4), 261-288. doi:10.1177/1524838002237330

Tourangeau, R., \& Yan, T. (2007). Sensitive questions in surveys. Psychological Bulletin, 133(5), 859-883. doi:10.1037/00332909.133.5.859

Tucker, J.B. (2003 September). Strategies for countering terrorism: Lessons from the Israeli experience. Journal of Homeland Security. Retrieved from http://www.homelanddefense.org/ journal/Articles/tucker-israel.html.
Van den Broek, H. (2004). BORROKA - The legitimation of street violence in the political discourse of radical basque nationalists. Terrorism and Political Violence, 16(4), 714-736. doi:10.1080/095465590885141

Winkel, F.W. (2007). Post traumatic anger. Missing link in the wheel of misfortune. Nijmegen: Wolf Legal Publishers.

Received July 31, 2009

Revision received February 24, 2010

Accepted March 24, 2010 